\title{
EFEKTIVITAS BIMBINGAN KELOMPOK TEKNIK HOME ROOM UNTUK MENINGKATKAN KOHESIVITAS KELOMPOK SISWA
}

\author{
${ }^{1}$ Ahmad Sa'id Mutohhari, ${ }^{2}$ Fakhruddin Mutakin, ${ }^{3}$ Yurike Kinanthy Karamoy \\ ${ }^{1}$ Mahasiswa Prodi Bimbingan dan Koneling, FKIP, Universitas Islam Jember, Indonesia \\ ${ }^{2}$ Dosen Prodi Bimbingan dan Koneling, FKIP, Universitas Islam Jember, Indonesia \\ ${ }^{3}$ Dosen Prodi Bimbingan dan Koneling, FKIP, Universitas Islam Jember, Indonesia \\ Email :ahmadsaid2302@gmail.com, fakhrudcounseling@gmail.com,yurikekinanthy14@gmail.com
}

\begin{abstract}
ABSTRAK
Penelitian ini dilaksanakan untuk mengetahui sejauh mana efektivitas layanan bimbingan kelompok teknik home room untuk meningkatkan kohesivitas kelompok siswa kelas XII IPA 2 SMA Negeri 3 Jember. Metode penelitian yang digunakan yaitu metode eksperimen dengan desain penelitian one group pretest and posttest design. Metode penentuan sampel menggunakan purposive sampling, yaitupenetuan sampel berdasarkan kriteria yang ditentukan. Berdasarkan hasil pretestyang dilakukan, diperoleh 6 konseli yang akan menjadi sampel penelitian. Adapun metode analisis data menggunakan analisis uji-t. Penelitian ini dilakukan dengan memberikan layanan bimbingan kelompok teknik home room sebanyak 5 kali layanan, dengan materi yang telah disusun sesuai dengan indikator kohesivitas dan analisis kebutuhan siswa. Berdasarkan analisis data yang dilakukan, diperoleh hasil uji-t sig.(2-tailed) $0,00<0,05$. Sehingga $H_{a}$ diterima dan $H_{0}$ ditolak, dengan kesimpulan bahwa layanan bimbingan kelompok teknik home room efektif untuk meningkatkan kohesivitas kelompok siswa kelas XII IPA 2 SMA Negeri 3 Jember.
\end{abstract}

Kata Kunci: Home room, Kohesivitas Kelompok

\begin{abstract}
This study was conducted to determine the extent of the effectiveness of home room engineering group guidance services to improve cohesiveness of students in class XII Science 2 of SMA Negeri 3 Jember. The research method used is an experimental method with one group pretest and posttest design research design. The method of determining the sample using purposive sampling, namely determining the sample based on specified criteria. Based on the results of the pretest conducted, obtained 6 counselees who will be the research sample. The data analysis method uses t-test analysis. This research was conducted by providing home room engineering group guidance services 5 times, with materials that have been prepared in accordance with indicators of cohesiveness and analysis of student needs. Based on the data analysis, the results of the t-test sig. (2-tailed) $0.00<0.05$. So Ha was accepted and Ho was rejected, with the conclusion that the home room engineering group guidance service was effective in increasing the cohesiveness of students of class XII Science 2 of SMA Negeri 3 Jember.
\end{abstract}

Keywords: Home Room, Group Cohesiveness 


\section{PENDAHULUAN}

Kegiatan siswa di sekolah tidak lepas dari kehidupan sosial dengan teman sekolah maupun teman kelas, karena pada hakikatnya siswa adalah makhluk sosial, yang artinya siswa tersebut membutuhkan orang lain dalam memenuhi kebutuhan, baik itu kebutuhan secara fisik maupun psikologis. Kelas dapat menjadi tempat pelatihan bagi siswa untuk membentuk kelompok yang kohesif. Siswa di kelas dapat belajar bagaimana cara membentuk kelompok yang kohesif dengan teman kelasnya, mengingat banyaknya jumlah teman yang ada dalam satu kelas, dimana setiap individu memiliki perbedaan kepribadian yang akan menambah banyak pengalaman bagi siswa. Kondisi kelas yang kohesif, akan berpengaruh terhadap suasana dalam kelas, kelas menjadi lebih hangat, akrab dan proses belajar di dalam kelaspun akan menjadi efektif. Hubu-ngan antar siswa mempengaruhi kenyamanan dalam kelas. Apabila siswa merasa nyaman bersama teman, merasa diterima maka hal ini akan mendukung proses belajar mengajar. Proses belajar mengajar yang baik adalah adanya interaksi dari semua pihak baik siswa dengan siswa maupun siswa dengan guru. Kohesivitas dan interaksi yang baik ini akan menunjang hubungan antar siwa dan berpengaruh terhadap semangat belajar di dalam kelas.

Aspek penting dari kelompok yang efektif adalah kohesivitas yang merupakan faktor utama dari kebera-daan kelompok. Ketertarikan pada keanggotaan kelompok dari setiap anggota kelompok menggambarkan kohesivitas kelompok. Oleh karena itu, kohesivitas kelompok dapat didefinisikan sebagai sejumlah faktor yang mempengaruhi anggota kelom-pok untuk menjadi anggota kelompok tersebut (Sitti Hartinah: 2009:72).

Hasil observasi awal di kelas XII IPA 2 SMA NEGERI 3 JEMBER tidak semua siswa mampu berinteraksi dengan baik antara teman sebaya. Kebanyakan siswa memilihmilih dalam berteman, hanya mau berteman dengan orang tertentu saja. Siswa memilih membentuk sebuah kelompok kecil dan enggan untuk bergabung dengan teman satu kelas. Mereka membatasi diri dan tidak akan membiarkan orang lain masuk dalam kelompok tersebut. Terbentuknya kelompok kecil dalam kelas maka suasana dalam kelas menjadi kurang kompak, karena setiap siswa fokus pada kelompoknya masing-masing, bukan pada kelas.

Hasil wawancara dengan beberapa siswa di kelas, siswa lebih sering berkumpul dengan kelompok kecilnya saat istirahat ataupun saat belajar. Mereka lebih nyaman dengan anggota kelompoknya dan tidak peduli dengan teman kelas yang lain, karena yang terpenting bagi mereka adalah teman satu kelompoknya. Ada siswa yang mengatakan malasuntuk berkomu-nikasi dengan teman diluar kelom-poknya, karena merasa berbeda pendapat dan pemikiran. Posisi duduk dalam kelaspun berdekatan dengan teman kelompoknya tersebut. Saat istirahat siswa juga selalu bersama kelompoknya, dan komunikasi dengan teman yang lain yang tidak masuk dalam kelompoknya terbilang jarang. Antar kelompok seperti memiliki batasan untuk berbaur dengan teman lainnya. 
Menurut Bimo Walgito (2006:47) Kohesivitas kelompok adalah saling tertariknya atau saling senangnya anggota satu dengan yang lain dalam kelompok. Dengan demikian, ting-katan kohesi akan dapat mempenga-ruhi interaksi anggota dalam kelom-pok. Dalam interaksi, apabila siswa tertarik pada siswa lain maka siswa akan mengadakan interaksi dengan siswa bersangkutan. Sebaliknya, bila siswa tidak tertarik, maka siswa tidak akan mengadakan interaksi. Dengan demikian, unsur ketertarikan sese-orang akan ikut menentukan terjadinya interaksi. Ketertarikan secara tidak langsung akan berpengaruh pada kohesivitas kelompok, yaitu melalui interaksi.

Berdasarkan masalah tersebut, diketahui bahwa terdapat beberapa metode untuk meningkatkan kohesi-vitas kelompok. Cara yang paling efektif adalah dengan membentuk hubungan yang kooperatif antar siswa (Hartinah: 2009:73). Hubungan yang kooperatif adalah yang memiliki keterbukaan. Keterbukaan itu sendiriadalah membagi informasi, ide, pemikiran, perasaan, dan reaksi dalam menyelesaikan masalah. Keterbukaan dapat terbentuk dengan membuat suasana kekeluargaan antar siswa melalui layanan bimbingan kelompok teknik home room. Metode ini dirasa efektif karena dalam teknik home room yang ditekankan adalah suasa-na kekeluargaan, seperti suasana rumah yang menyenangkan dan akrab, siswa merasa aman dan nyaman sehingga siswa dapat mengungkapkan masalah-masalah yang tak dapat dibicarakan dalam kelas pada waktu jam pelajaran bidang studi. Melalui terciptanya suasana kekeluargaan dalam bimbingan kelompok teknik home room, masalah rendahnya kohesivitas siswa dapat terselesaikan karena siswa tidak canggung dalam mengungkapkan masalahnya kepada anggota lain, sehingga akan terjadi disuksi mengenai materi yang sudah ditentukan sebelumnya.

Berdasarkan studi pendahuluan dan latar belakang masalah yang telah diuraikan, maka pada penelitian ini, peneliti melakukan uji coba efektivitas layanan bimbingan kelompok teknik home room untuk meningkatkan kohesivitas kelompok siswa kelas XII IPA 2 SMA NEGERI 3 JEMBER.

\section{METODE}

Metode penelitian yang digunakan dalam penelitian ini adalah penelitian eksperimen dengan desain preeksperimental design. Penelitian eksperimen dapat diartikan sebagai metode penelitian yang digunakan untuk mencari pengaruh perlakuan tertentu terhadap yang lain dalam kondisi yang terkendalikan (Sugiono: 2017:72). Preeksperimental design dipilih karena dalam penelitian ini, masih terdapat variabel luar yang ikut berpengaruh terhadap terbentuknya variabel dependen. Jadi hasil eksperimen yang merupakan variabel dependen itu bukan semata-mata dipengaruhi variabel independen. Hal ini dapat terjadi karena tidak adanya variabel kontrol, dan sampel tidak dipilih secara random.

Bentuk desain yang digunakan adalah one group pre-test- post-test design, yaitu suatu kelompok yang diberi pre-test sebelum diberi perlakuan, dan diberi posttest pada akhir penelitian, dengan rancangan satu kelompok tanpa kelompok 
pembanding. Desain penelitian ini dapat dilihat pada gambar berikut.

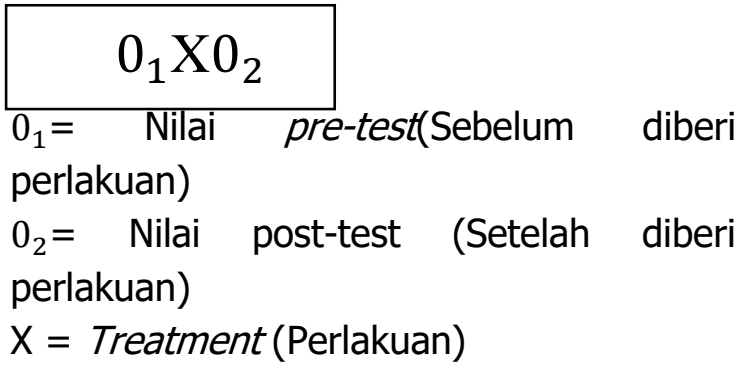

Sumber: Prof. Dr. Sugiono, 2017: 74

Variabel bebas (independent variable) pada penelitian ini adalah layanan bimbingan kelompok teknik home room, sedangakan variabel terikat (dependent variable) adalah kohesivitas kelompok.

Populasi penelitian ini adalah seluruh peserta didik kelas XII IPA 2 SMA NEGERI 3 JEMBER yang berjumlah 35 siswa. Sampel penelitian akan dipilih beberapa siswa dari populasi tersebut berdasarkan kriteria tertentu dengan menggunakan teknik sampling purposive, yaitu teknik penentuan sampel dengan pertimbangan tertentu (sugiono: 2017: 85). Adapun kriteria tersebut antara lain: (1)
Merupakan siswa kelas XII IPA 2, (2) Terinden-tifikasi sebagai siswa yang memi-liki kohesivitas kelompok kategori rendah dan sedang berdasarkan hasil pengukuran skala kohesi-vitas.

Pada penelitian menggunakan metode skala untuk pengumpulan data. Skala Likert digunakan untuk mengukur sikap, pendapat, dan persepsi seseorang terhadap fenomena sosial. Skala kohesivitas digunakan untuk mengukur tingkat kohesivitas siswa. Skala ini digunakan untuk mengukur kohesivitas kelompok sebelum diberi perlakuan (pretest) dan setelah diberi perlakuan (posttest).

Rentangan penilaian pada skala kohesivitas ini menggunakan skor 1-5 dengan jumlah item 22, sehingga interval kriteria tersebut dapat ditentukan dengan cara sebagai berikut:

Skor tertinggi : $22 \times 5=110$

Skor terendah : $22 \times 1=22$

Interval $\quad:(110-22): 5=17,6$

Tabel 1. Klasifikasi Skor Pencapaian Skala Kohesivitas

\begin{tabular}{cc}
\hline Skor & Kategori \\
\hline $22-38,6$ & Sangat Rendah \\
$39,6-56,2$ & Rendah \\
$57,2-73,8$ & Sedang \\
$74,8-91,4$ & Tinggi \\
$92,4-110$ & Sangat Tinggi \\
\hline
\end{tabular}

Sumber : Data Diolah

Analisis data merupakan kegiatan setelah data dari seluruh responden atau sumber data lain terkumpul. Kegiatan dalam analisis data adalah: mengelompokkan data berdasarkan variabel dan jenis responden, menabulasi data berdasarkan variabel dari seluruh responden, menyajikan data tiap variabel yang diteliti, melakukan penghitungan untuk menjawab rumusan masalah, dan melakukan penghitungan untuk menguji hipotesis yang telah diajukan (Sugiono: 2015: 76). Metode analisis data yang digunakan dalam penelitian ini adalah 
analisis statistik inferensial dengan menggunakan statistik parametrik uji-t. Uji statistik pada penelitian ini menggunakan program SPSS 20. Apabila harga sig.(2tailed) $<0,05$, maka Ha diterima dan $\mathrm{Ho}$ ditolak, sehingga dapat disimpulkan bahwa bimbingan kelompok teknik home room efektif untuk meningkatkan kohesivitas kelompok.

\section{HASIL DAN PEMBAHASAN}

Penelitian ini dilaksanakan dengan memberikan layanan bimbingan kelompok teknik home room kepada siswa kelas XII IPA 2 SMA Negeri 3 Jember untuk meningkatkan kohesivitas kelompok. Kegiatan penelitian dilaksanakan mulai tanggal 26 Juli 2019 hingga 27 September 2019, dengan memberikan 5 kali layanan. Sampel penelitian ditentukan berdasarkan skor hasil pretest yang dilakukan, dan sesuai dengan kriteria yang diinginkan, sehingga diperoleh 6 siswa yang memiliki kohesivitas kelompok kategori rendah dan sedang yang digunakan sebagai sampel penelitian.

Berdasarkan hasil pretest dan posttest yang diperoleh, dan hasil analisis uji hipotesis yang dilakukan, diketahui bahwa nilai sig.(2-tailed) adalah 0,00 0,05. Sehingga $\mathrm{H}_{\mathrm{a}}$ diterima dan $\mathrm{H}_{\mathrm{o}}$ ditolak, dengan kesimpulan bahwa layanan bimbingan kelompok teknik home room efektif meningkatkan kohesivitas kelompok siswa kelas XII IPA 2 SMA Negeri 3 Jember. Berdasarkan hasil analisis menunjukkan bahwa terdapat perbedaan hasil skor skala kohesivitas sebelum dan sesudah diberi layanan. Peningkatan skor tersebut diperoleh setelah siswa (konseli) mengikuti layanan bimbingan kelompok teknik home room.

\section{SIMPULAN}

Penelitian ini dilaksanakan untuk mengetahui efektivitas layanan bimbingan kelompok teknik home roomuntuk meningkatkan kohesivitas kelompok siswa kelas XII IPA 2 SMA Negeri 3 Jember. Berdasarkan hasil penelitian yang dilakukan, terdapat dua kesimpulan yaitu:

a. Terdapat siswa yang memiliki kohesivitas kelompok rendah. Hal ini diketahui dengan melihat skor hasil pengisian skala kohesivitas yang diberikan sebelum pemberian layanan.

b. Layanan bimbingan kelompok teknik home room efektif meningkatkan kohesivitas kelompok siswa kelas XII IPA 2 SMA Negeri 3 Jember. Hal ini diketahui dengan membandingkan skor hasil pretest dan posttest yang dilakukan, dan mengujinya dengan analisis uji-t menggunakan program SPSS 20. Hasilnya menunnjukkan bahwa nilai sig.(2-tailed) 0,00<0,05. Sehingga dapat disimpulkan bahwa layanan bimbingan kelompok teknik home room efektif meningkatkan kohesivitas kelompok siswa kelas XII IPA 2 SMA Negeri 3 Jember.

Bagi peneliti selanjutnya disarankan untuk dapat mene- rapkan penelitian ini dalam subyek yang lebih luas, sehingga hasilnya dapat digeneralisasikan. Peneliti dapat menambah sumber lain atau menggunakan teknik yang berbeda, sehingga hasil penelitian akan menjadi lebih variatif.

\section{DAFTAR PUSTAKA}

Arifin, Bambang Syamsul. 2015. Dinamika Kelompok. Bandung: Pustaka Setia 
Dewi, Tria Ratna.2012. Pelaksanaan layanan bimbingan kelompok dengan teknik home room untuk meningkatkan kepercayaan diri siswa dalam bidang akademik di SMK Kartika 2 Surabaya

Faturrochman, 2006. Pengantar Psikologi Sosial. Yogyakarta:

Pustaka

Hartinah, Sitti. 2009. Konsep Dasar Bimbingan Kelompok. Bandung: Refika Aditama

Nur, Arifin. 2019. Buku Pedoman Penyusunan Proposal dan Skripsi. Surabaya: Pustaka Radja

Nurihsan, Ahmad Juntika. 2009. Bimbingan dan Konseling dalam Berbagai Latar Kehidupan. Bandung: Refika Aditama

Nursalim, 2002. Layanan Bimbingan dan Konseling. Surabaya Unesa University Press
Romlah,Tatiek. 2006. Teori dan Praktek Bimbigan Kelompok. Malang: Universitas Negeri Malang

Salahudin, Anas.2010. Bimbingan danKonseling. Bandung. CV.

Pustaka Setia

Sukardi, Dewa Ketut. 2008. Pengantar Pelaksanaan Program Bimbingan dan Konseling di Sekolah. Jakarta: Rineka Cipta

Sugiono. 2015. Cara Mudah Menyusun Skripsi, Tesis dan Disertasi. Bandung: Alfabeta

Kualitatif ' ${ }^{\prime}$ Kuntitatif Bandung: Alfabeta

Tohirin. 2007. Bimbingan dan Konseling di Sekolah dan Madrasah (Berbasis Integrasi). Jakarta: Raja Grafindo Persada.

Walgito, Bimo. 2006. Psikologi

Kelompok. Yogyakarta: Andi

Offset 